\title{
SYNTHESIS OF NEW Pt(II) COMPLEX BEARING ORGANOSELENIUM LIGANDS AND EVALUATION OF CYTOTOXIC ACTIVITY OF SOME STRUCTURALLY RELATED Pd(II) COMPLEXES
}

\author{
Ninko Radenković1, Marina D. Kostić2 , Nataša Z. Đorđević3 ${ }^{3}$ Zana C. Dolicanin ${ }^{3}$, \\ Tanja V. Soldatovićc ${ }^{4}$ Marko N. Živanoviće ${ }^{2}$, Vera M. Divac ${ }^{*}$ \\ ${ }^{1}$ U niversity of Kragujevac, Faculty of Science, Department of Chemistry, Radoja Domanovića 12, \\ 34000 Kragujevac, Serbia \\ 2 U niversity of Kragujevac, Institute for Information Technologies, Department of Science, \\ J ovana Cvijica bb, 34000 Kragujevac, Serbia. \\ ${ }^{3}$ State U niversity of Novi Pazar, Department of Biomedical Science, Vuka Karadžića bb, \\ 36300 Novi Pazar, Serbia. \\ ${ }^{4}$ State U niversity of N ovi Pazar, Department of Chemical-Technological Science, Vuka Karadžića bb, \\ 36300 Novi Pazar, Serbia \\ veradivac@kg.ac.rs
}

Herein we report the synthesis of a new trans-bis(2-phenylselenylmethyl)oxolane)dichloroplatinum(II) complex (Pt1). This newly synthesized complex, together with two structurally related trans-Pd(II) complexes, (trans-bis(2-(phenylselenylmethyl)oxolane) dichloropalladium(II) (Pd1) and trans-bis(2(phenylselenylmethyl)oxane)dichloropalladium(II) (Pd2), were screened for cytotoxic activity through in vitro studies on the HCT-116 colorectal carcinoma cell line and MRC-5 healthy lung pleura cell line. The activity of the complexes was assessed by comparing it to cisplatin. The cells' viability and proliferation were determined using an MTT (Microculture Tetrazolium Test) assay.

Keywords: organoselenium chemistry; palladium; platinum; cytotoxic activity; colon carcinoma

\section{СИНТЕЗА НА НОВ Рt(I)-КОМПЛЕКС СО ОРГАНОСЕЛЕНОВИ ЛИГАНДИ И ЕВАЛУАЦИЈА НА ЦИТОТОКСИЧНАТА АКТИВНОСТ НА НЕКОИ СТРУКТУРНО СРОДНИ РО(І)-КОМПЛЕКСИ}

Во овој труд ја објавуваме синтезата на нов комплекс на trans-бис(2-фенилселенилметил)оксолан) дихлороплатина(II) (Pt1). Овој новосинтетизиран комплекс, заедно со два структурно сродни комплекси на trans-Pd(II), [trans-бис(2-фенилселенилметил)оксолан)дихлоропаладиум(II) (Pd1) и trans-бис(2-(фенилселенилметил)оксан)дихлоропаладиум(II) (Pd2)], беa испитани за цитотоксична активност преку in vitro истражување со колоректалната линија НСТ-116 за карциномски клетки, како и со линијата MRC-5 за здрави клетки на белодробната плевра. Активноста на комплексите беше определена со споредба со цисплатин. Способноста за опстанок на клетките и нивното размножување беше определено со тестот МТT (Microculture Tetrazolium Test).

Клучни зборови: органоселенова хемија; паладиум; платина; цитотоксична активност; карцином на дебело црево

\section{INTRODUCTION}

Organoselenium compounds are known for their huge capacity for transformation and functionalization under very mild experimental conditions.
Apart from the undoubted importance of these compounds as reaction intermediates and reagents, there is immense scientific interest in their biological activities, such as antioxidant, anti-inflammatory, 
neuroprotection, chemotherapeutic, and chemopreventive activities $[1,2]$. The promising new development of these compounds is certainly represented by their ability to coordinate with transition metal ions, thus, constituting a new class of building blocks [3]. The coordination of biologically active molecules to transition metals can provide significant new activity due to their unique ability to interact with different biological targets [4].

Selenium, as an oligoelement, is involved in many cellular processes that are manifested in a variety of essential biological functions, which makes selenium compounds one of the most extensively studied class of molecules. Selenium compounds are proven to possess antioxidant properties and play a significant role in cancer prevention and treatment therapies. Transition metal complexes bearing organoselenium ligands represent an attractive subset of the organoselenium chemistry. The major factors contributing towards extensive investigation of transition metal complexes with organoselenium compounds as ligands are derived from the identification of their catalytic, biological, and biomedical properties [3, 5-7]. Several research groups have devoted efforts to preparation of these types of complexes, as they have been proven to exhibit antidiabetic [8], antioxidant, antimalarial, antitumor, antileukemic, and cytotoxic activity [9-14], thus rising as promising new pharmaceutical agents.

Platinum-based complexes have been considered as potent therapeutic agents for tumors, due to their ability to bind guanine and adenine residues on DNA chains and, in that way, cause changes in DNA structure and induce cancer cell apoptosis. Some of the most utilized platinum compounds in cancer therapies are cisplatin, carboplatin, and oxaliplatin, which are either applied alone or in the form of combination therapy with other chemotherapy drugs $[15,16]$. Although platinum complexes have shown excellent results in treatment towards certain cancer cell lines, their usage is limited, owing to the many side effects, such as nephrotoxicity, gastrointestinal toxicity, neurotoxicity and ototoxicity. Side effect deficiencies, combined with limited applicability, have dictated further pursuit for adequate alternatives. In recent years, a vast number of new $\mathrm{Pd}(\mathrm{II})$ complexes with promising antitumor capacities were synthesized [17, 18]. Pd(II) complexes, unlike their Pt(II) analogs, have shown better solubility [19], and in addition to displaying significant anti-tumor activity, they express fewer side effects $[20,21]$. It is established that the trans-geometry of the $\mathrm{Pd}(\mathrm{II})$ center is responsible for lower toxicity and higher cytotoxicity compared to its cis-isomer. To minimize any possible cis-trans isomerism, relatively bulky monodentate ligands are used for their synthesis [17].

The proper selection of ligands around the metal center governs the reactivity and performance of the complex. Organoselenium compounds are still rarely used as ligands, compared to the vast amount of reported sulfur-based complexes. In this work, the synthesis of a new Pt(II) complex bearing two bulky organoselenium ligands in the trans position and the evaluation of cytotoxic activity of the $\mathrm{Pt}(\mathrm{II})$-organoselenium complex, as well as its $\mathrm{Pd}(\mathrm{II})$ analogs, on the HCT-116 colorectal carcinoma and the MRC-5 healthy lung pleura cell lines is reported. The major outcome of this study is the synthesis of the new organoselenium-based Pt(II) complex, Pt1, and comparison of its cytotoxicity towards the cytotoxicity of the structurally-related Pd complexes, Pd1 and Pd2.<smiles>ClP(CC1CCCO1)[Se](CC1CCCO1)([Se](Cl)c1ccccc1)[Se](Cl)c1ccccc1</smiles>

Pd1<smiles>CCO[PH](=O)(=O)C[Se](Cl)([Se]c1ccccc1)[Se](Cl)(CC1CCCCO1)c1ccccc1</smiles><smiles>[SeH]c1ccccc1</smiles>

L1<smiles>[SeH]c1ccccc1</smiles>

L2<smiles>ClP([Se](CC1CCCO1)c1ccccc1)[P+](Cl)(CC1CCCO1)[Se]c1ccccc1</smiles>

Scheme 1. The complexes and ligands used in this study (top). The synthesis of the Pt1 complex (bottom). 


\section{EXPERIMENTAL}

\subsection{Instrumentation}

${ }^{1} \mathrm{H}$ NMR (Nuclear Magnetic Resonance) spectra were run in $\mathrm{CDCl}_{3}$ on a Varian Gemini 200 $\mathrm{MHz}$ NMR spectrometer. Elemental analyses were performed on a Vario III C, H, N, S Elemental Analyzer in CHS mode. Mass spectrometry (MS) was performed on a Waters SYNAPT G2-Si/nanoACQUITY UPLC system. Thin-layer chromatography (TLC) was carried out on $0.25 \mathrm{~mm} \mathrm{E}$. Merck precoated silica gel plates $(60 \mathrm{~F}-254)$ using UV light for visualization. For column chromatography, E. Merck silica gel (60, particle size 0.063 $0.200 \mathrm{~mm}$ ) was used.

\subsection{Synthesis and complexation of $L 1$ and $L 2$ with $\mathrm{Pd}(\mathrm{II})$ and $\mathrm{Pt}(\mathrm{II})$}

Ligand compounds $\mathbf{L 1}$ and $\mathbf{L 2}$ were synthesized in high yields according to a previously reported method [22]. Complexes Pd1 and Pd2 were obtained by the given general procedure [23]. All reagents and solvents were commercially available and used as received, without further purification.

Pt1 complex was obtained by the following procedure. First, $\mathrm{K}_{2} \mathrm{PtCl}_{4}(0.33 \mathrm{mmol}, 0.137 \mathrm{~g})$ was added in excess to a solution of ligand compound $\mathbf{L 1}(0.3 \mathrm{mmol}, 0.072 \mathrm{~g})$ in a mixture of $8 \mathrm{ml}$ of EtOH (ethanol) and $2 \mathrm{ml}$ of $\mathrm{MeOH}$ (methanol). The resulting mixture was stirred at $40{ }^{\circ} \mathrm{C}$ for $5 \mathrm{~h}$, and the color changed from dark red to bright yellow. The precipitate was filtered off, and the solution was concentrated by slow evaporation of the solvent. The obtained solid was collected, air dried, and recrystallized from EtOH.

Compound Pt1: Bright yellow, needleshaped crystals (EtOH). Yield $(0.073 \mathrm{~g}, 89 \%) .{ }^{1} \mathrm{H}$ NMR $\left(\mathrm{CDCl}_{3}, 200 \mathrm{MHz}, 25^{\circ} \mathrm{C}, \mathrm{TMS}\right): \delta 7.95$ (m, $2 \mathrm{H}, \mathrm{Ph}), 7.39(\mathrm{~m}, 3 \mathrm{H}, \mathrm{Ph}), 4.24$ (quint, $1 \mathrm{H}, \mathrm{CHO}$ ), $3.8(\mathrm{~m}, 1 \mathrm{H}, \mathrm{CHaHbO}), 3.58(\mathrm{~m}, 1 \mathrm{H}, \mathrm{CHaHbO})$, $3.55\left(\mathrm{dd}, \mathrm{J}_{1}=7.8 \mathrm{~Hz}, \mathrm{~J}_{2}=17 \mathrm{~Hz}, 1 \mathrm{H}, \mathrm{CHa} \underline{\mathrm{HbSe}}\right)$, $3.29\left(\mathrm{dd}, \mathrm{J}_{1}=5.8 \mathrm{~Hz}, \mathrm{~J}_{2}=12.5 \mathrm{~Hz}, 1 \mathrm{H}, \mathrm{CHaHbSe}\right)$, 1.52-2.1 (m, $\left.4 \mathrm{H}, 2 \mathrm{CH}_{2}\right)$; $\mathrm{MS}: \mathrm{m} / \mathrm{z}=748.12$. Anal. $\mathrm{C}_{22} \mathrm{H}_{28} \mathrm{Cl}_{2} \mathrm{O}_{2} \mathrm{PtSe}_{2}\left(\mathrm{M}_{\mathrm{r}}=748.36\right)$ : calcd. C $35.29, \mathrm{H}$ 3.74; found: C 35.18, H 3.80 .

\subsection{Cell cultures and treatment}

In this study, we used human colorectal cancer cell line HCT-116 to test the anticancer activity of the synthesized complexes. The HCT-116 colorectal cancer cell line was purchased from the American Type Culture Collection (ATCC, Manassas, VA, USA). The cells were cultured in DMEM
(Dulbecco's Modified Eagle Medium, Gibco, USA) and were supplemented with $10 \%$ fetal calf serum and penicillin (100 IU/ml)/streptomycin (100 $\mu \mathrm{g} / \mathrm{ml}$ ) in a $5 \% \mathrm{CO}_{2}$ humidified atmosphere at 37 ${ }^{\circ} \mathrm{C}$. The cells' viability and proliferation were determined at $80 \%$ to $85 \%$ confluence using the MTT assay. Cells were seeded in 96-well plates at a predetermined density $\left(10^{4}\right.$ cells per well) and incubated for $24 \mathrm{~h}$ at $37{ }^{\circ} \mathrm{C}$ in a humidified atmosphere containing $5 \% \mathrm{CO}_{2}$. After $24 \mathrm{~h}$, the medium was replaced with $100 \mu \mathrm{l}$ of a solution with various concentrations of cisplatin and synthesized complexes, which had been serially diluted two-fold in the concentration range of 500 to $3.9 \mu \mathrm{M}$ in DMEM medium. Untreated cells were used as controls. Cells were incubated at $37{ }^{\circ} \mathrm{C}$ and in $5 \% \mathrm{CO}_{2}$ in a humidified atmosphere for $24 \mathrm{~h}$ and $72 \mathrm{~h}$. The controls and synthesized compounds were tested in triplicate by three independent tests.

\subsection{Cell viability and proliferation assay (M TT assay)}

After 24 and $72 \mathrm{~h}$ of treatment, the cells' viability and proliferation were determined using a MTT assay [24]. The MTT assay is based on the reduction of yellow tetrazolium salt MTT (3-[4,5-dimethylthiazol-2-yl]-2,5-diphenyltetrazoliumbromide) by mitochondrial dehydrogenase of living cells to soluble purple formazan. At the end of the treatment period, the cells were washed with PBS, and then, $100 \mu$ l of the MTT solution, at final concentration $5 \mathrm{mg} / \mathrm{ml}$, was added to each well. Cells were incubated in a $5 \% \mathrm{CO}_{2}$ humidified atmosphere at $37{ }^{\circ} \mathrm{C}$ for $3 \mathrm{~h}$. After incubation, the MTT solution was discarded, and colored crystals of the produced formazan were dissolved in $150 \mu \mathrm{l}$ of dimethyl-sulfoxide (DMSO). The absorbance values were measured on a microplate reader at $550 \mathrm{~nm}$. Cell viability was calculated as the ratio of the absorbance of treated group divided by the absorbance of the control group, multiplied by 100 to give the percent viability.

The data were expressed as the means \pm standard errors (S. E.). The effects of cisplatin and each synthesized complex were expressed by $\mathrm{IC}_{50}$, which is the half-maximal growth inhibitory concentration. The $\mathrm{IC}_{50}$ values were calculated from the dose curves by a computer program (CalcuSyn).

\section{RESULTS AND DISCUSSION}

In our previous work, we screened 2(phenylselenylmethyl)oxolane (L1, Scheme 1) and 2-(phenylselenylmethyl)oxane (L2, Scheme 1) for 
their antioxidant and antiproliferative effects on colon cancer cell line HCT-116 and breast cancer cell line MDA-MB-231 [25]. Not only did they show no evidence of cytotoxic effects, but they exhibited an even more stimulated proliferation of the colon cancer cell line, HCT-116, during the treatments at 24 and $72 \mathrm{~h}$. Although these compounds did not show cytotoxic effects, they have proven to be great scavengers for reactive oxygen species, expressing significant antioxidant effects. As a continuation of this work, we have synthesized two Pd(II) complexes using these organoselenium compounds, L1 and L2, as ligands: $\left[\mathrm{PdL1}_{2} \mathrm{Cl}_{2}\right]$ (Pd1, Scheme 1) and $\left[\mathrm{Pd} \mathbf{L} \mathbf{2}_{2} \mathrm{Cl}_{2}\right](\mathbf{P d} 2$, Scheme 1). Complexes Pd1 and Pd2 were characterized, and their crystal structures were determined. Following this, the antimicrobial properties of these complexes were investigated against a series of human pathogenic bacterial and fungal strains [23]. The complexes exhibited promising, though moderate, broad spectrum antimicrobial activity that was more pronounced against fungal organisms. Also, the reactivity of these complexes towards small bio-molecules, such as L-Cys (L-Cysteine), GSH (Glutathione), L-Met (L-Methionine), 5'-GMP (Guanosine monophosphate), and L-His (L-Histidine), was assessed by a kinetic study, where Pd1 was found to be the most reactive. The interaction of complexes $\mathrm{Pd} 1$ and $\mathrm{Pd} 2$ with calf thymus DNA (CT-DNA) was also examined by absorption (UV-Vis) and emission spectral studies (EtBr displacement studies), and Pd1 was found to have the greatest affinity towards CT-DNA compared to other investigated organoselenium-palladium(II) complexes [26].

Based on the results from previous studies, we have synthesized a new Pt(II) analog of complex Pd1: $\left[\mathrm{Pt}(\mathrm{II}) \mathbf{L 1}_{2} \mathrm{Cl}_{2}\right]$ (Pt1, Scheme 1). Considering the stability of the metal-selenium bond and the high affinity of these complexes towards bio-molecules and DNA, our goal was to determine whether these interactions can lead to the manifestation of some anticancer properties for these complexes. Further, we wanted to establish the influence of (a) the central metal ion (Pd vs. Pt) on potential cytotoxicity and (b) the nature of the ligands' cyclic ether moiety on potential cytotoxicity.

This new Pt complex was synthesized under very mild reaction conditions, as depicted in
Scheme 1. In contrast to the synthesis of the Pd analogs, the reaction time was significantly longer. While complexation of the selenium ligand with the $\mathrm{Pd}$ center was completed in $3 \mathrm{~h}$, the reaction with the Pt center yielded only 30-35\% of the desired product in the same reaction time. By extending the reaction time to $48 \mathrm{~h}$, a significant increase in yield (up to 89 $\%$ ) was observed. The structure of the compound was determined with spectroscopic methods $\left({ }^{1} \mathrm{H}\right.$ NMR and MS) and elemental analysis. The formation of the Pt(II) complex with the organoselenium ligand via the Pt-Se bond is best seen by the difference in spectral shifts of the free ligand and complexed one in ${ }^{1} \mathrm{H}$ NMR (Table 1).

\section{Table 1}

Significant ${ }^{(a)}{ }^{1} \mathrm{H}$ chemical and coordination shifts for the free ligand $\mathbf{L} \mathbf{1}$ and the corresponding Pt1 complex in $\mathrm{CDCl}_{3}$ and ambient temperature

\begin{tabular}{ccc}
\hline \hline Compound & L1 $^{\text {(b) }}$ & Pt1 \\
\hline $\mathrm{CHaHbSe}$ & 2.98 & 3.52 \\
$\mathrm{CHaHbSe}$ & 3.11 & 3.26 \\
$\mathrm{CHO}$ & 4.08 & 4.24 \\
$\mathrm{Ph}(3 \mathrm{H})$ & 7.27 & 7.39 \\
$\mathrm{Ph}(2 \mathrm{H})$ & 7.56 & 7.95 \\
\hline \hline
\end{tabular}

(a) Other signals were not significantly influenced by coordination. (b) Ref. 23.

In the present study, besides the synthesis of the novel Pt1 complex (Scheme 1), we evaluated the possible anticancer properties of complexes Pd1, Pt1, and Pd2, comparing the cytotoxic effects on human HCT-116 colorectal carcinoma and MRC-5 healthy lung pleura cells. The activity of the complexes was assessed by comparing them to cisplatin. The effects of various concentrations of cisplatin and complexes Pd1, Pt1, and Pd2 on cell viability after 24 and $72 \mathrm{~h}$ are presented in Figs. 1-4 in the supplementary information. The $\mathrm{IC}_{50}$ values are presented in Table 2.

All tested complexes had an observable effect on cell viability at all applied concentrations and reduced the viability of both cell lines in a dose-dependent manner, as shown by the results of MTT assay (Figs. 1-4 in the supplementary information). Complex Pt1 showed higher cytotoxic effects compared to the palladium complexes on both cell lines. 


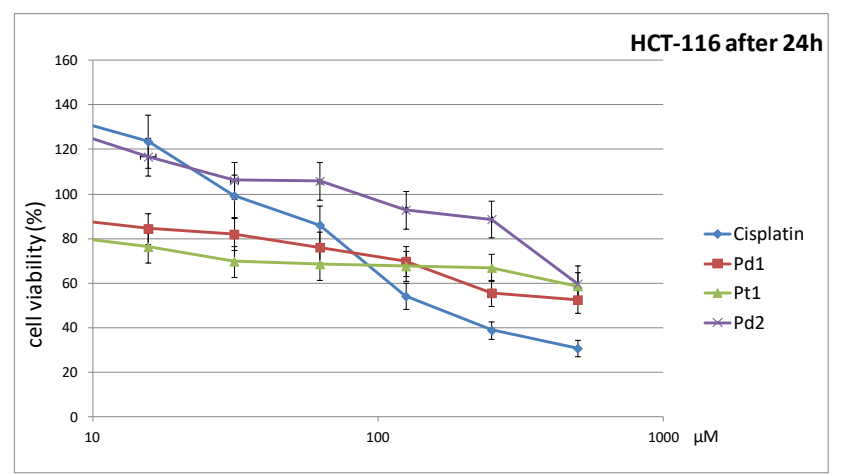

Fig. 1. Anticancer activity of cisplatin, Pd1, Pt1 and Pd2 on HCT-116 colorectal cancer cell line after $24 \mathrm{~h}$ of treatment. Results were expressed as the means \pm S.E. from three independent experiments.

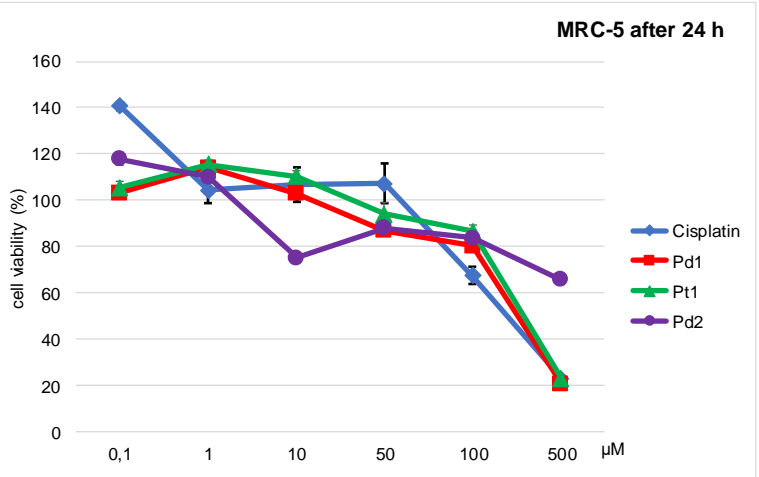

Fig. 2. Cytotoxic activity of cisplatin, Pd1, Pt1 and Pd2 on MRC-5 healthy lung pleura cell line after $24 \mathrm{~h}$ of treatment.

Results were expressed as the means \pm S.E. from three independent experiments.

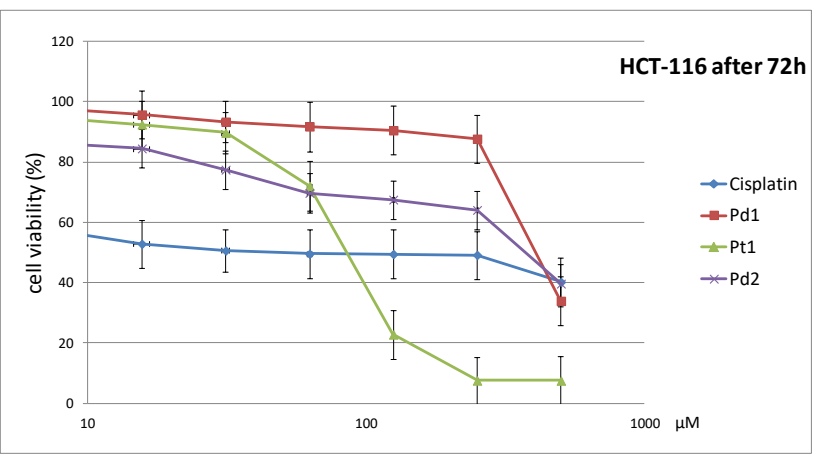

Fig. 3. Anticancer activity of cisplatin, Pd1, Pt1 and Pd2 on HCT-116 colorectal cancer cell line after $72 \mathrm{~h}$ of treatment.

Results were expressed as the means \pm S.E. from three independent experiments.

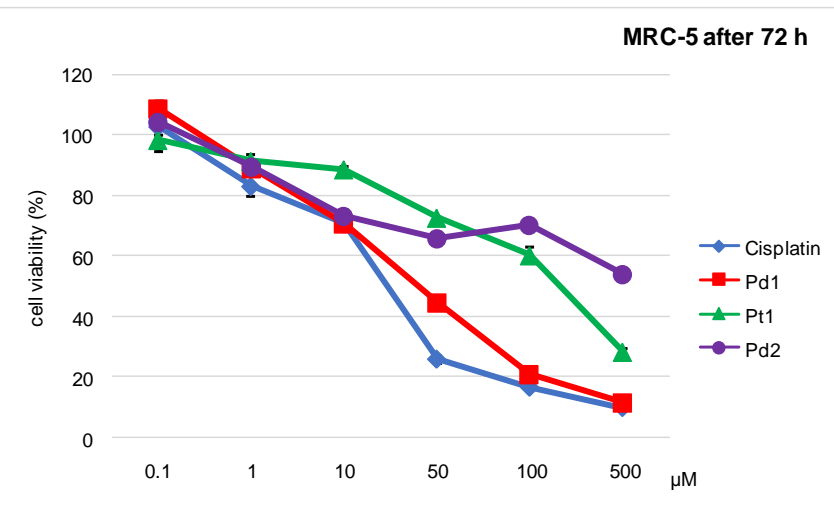

Fig. 4. Cytotoxic activity of cisplatin, Pd1, Pt1 and Pd2 on MRC-5 healthy lung pleura cell line after $72 \mathrm{~h}$ of treatment. Results were expressed as the means \pm S.E. from three independent experiments.

T a b le 2

Growth inhibitory concentration $\mathrm{IC}_{50}$ values $(\mu M)$ of cisplatin, Pd1, Pt1 and Pd2 on HCT-116 colorectal carcinoma and M RC -5 healthy lung pleura cell lines after 24 and $72 \mathrm{~h}$ of treatment

\begin{tabular}{lllll}
\hline \hline Treatment & \multicolumn{2}{c}{ HCT-116 } & \multicolumn{2}{c}{ MRC-5 } \\
\hline & $\mathbf{2 4} \mathbf{~ h}$ & $\mathbf{7 2} \mathbf{~ h}$ & $\mathbf{2 4} \mathbf{~ h}$ & $\mathbf{7 2} \mathbf{~ h}$ \\
\cline { 2 - 5 } Complex Pd1 & $>500$ & $>500$ & 70.95 & 34.85 \\
Complex Pt1 & $>500$ & 260.69 & $>500$ & 140.36 \\
Complex Pd2 & $>500$ & $>500$ & $>500$ & $>500$ \\
Cisplatin & 251.51 & 71.71 & 240.11 & 28.94 \\
\hline \hline
\end{tabular}

\section{CONCLUSIONS}

The coordination of organoselenium compounds to transition metals provides very interesting pharmacological properties, which arouses an interest for further research in this area. So far, the organoselenium moieties were primarily considered for their antioxidative effects and only recent, pioneering works have shown their potential in cytotoxicity. In this paper, we reported the cytotoxicity of $\mathrm{Pt}(\mathrm{II})$ and $\operatorname{Pd}$ (II) complexes with $\mathbf{L 1}$ and $\mathbf{L} 2$ as ligands. Among all investigated complexes, the platinum-based complex Pt1 showed the best results in the terms of the obtained $\mathrm{IC}_{50}$ values. Although, all complexes manifested higher $\mathrm{IC}_{50}$ values compared to cisplatin. At lower concentrations, the investigated complexes displayed better activity relative to cisplatin, especially in the case of the Pd1 and Pt1 complexes, which contain ligand L1 with a five-membered cyclic ether moiety (Figs. 1-4 in the supplementary information). Furthermore, this study showed that the platinumbased complex has better cytotoxic propriety than the palladium ones (Pt1 vs. Pd1 and Pd2) and that the five-membered cyclic ether moiety in the organoselenium ligand is more advantageous than the six- 
membered one (Pd1 and Pt1 vs. Pd2). Even so, as this area is still nascent and requires further investigation, it can be expected that existing results could inspire further developments in this field.

Acknowledgments. This work was funded by the Ministry of Education, Science and Technological Development of the Republic of Serbia (Grant: 172011 and III41010). This research is part of the thematic multidisciplinary network SeS Redox and Catalysis.

\section{REFERENCES}

[1] G. Mugesh, W. du Mont, H. Sies, The chemistry of biologically important synthetic organoselenium compunds, Chem. Rev. 101, 2125-2179 (2001).

[2] C. Sanmartín, D. Plano, A. K. Sharma, J. A. Palop, Selenium compounds, apoptosis and other types of cell death: an overview for cancer therapy, Int. J. Mol. Sci.; 13, 9649-9672 (2012)

[3] A. Kumar, G. K. Rao, F. Saleem, A. K. Singh, Organoselenium ligands in catalysis, J. Chem. Soc. Dalton. Trans.; 41, 11949-11977 (2012).

[4] E. Meggers, Exploring biologically relevant chemical space with metal complexes, Curr. O pin. Chem. Biol. 11, 287-292 (2007).

[5] E. G. Hope, W. Levason, Recent developments in the coordination chemistry of selenoether and telluroether ligands, Coord. Chem. Rev. 122, 109-170 (1993).

[6] M. K. Davies, M. C. Durrant, W. Levason, G. Reid, R. L. Richards, Synthesis, spectroscopic and structural studies on transition metal carbonyl complexes of cyclic di- and tetra-selenoether ligands, J. Chem. Soc. Dalton. Trans. 7, 1077-1084 (1999).

[7] J. Arnold, The Chemistry of M etal Complexes with Selenolate and Tellurolate Ligands. In: Progress in Inorganic Chemistry, K. D. Karlin (Ed), Hoboken: John Wiley \& Sons Inc, 1995, Vol. 43, pp. 353-417.

[8] S. Fujimoto, H. Yasui, Y. Yasukawa, Development of a novel antidiabetic zinc complex with an organoselenium ligand at the lowest dosage in KK-Ay mice, J. Inorg. $\mathrm{Bi}$ ochem. 121, 10-15 (2013).

[9] T. R. Todorovic, A. Bacchi, D. M. Sladic, N. M. Todorovic, T. T. Bozic, D. D. Radanovic, N. R. Filipovic, G. Pelizzi, K. K. Andjelkovic, Synthesis, characterization and biological activity evaluation of $\mathrm{Pt}(\mathrm{II}), \mathrm{Pd}(\mathrm{II}), \mathrm{Co}(\mathrm{III})$ and $\mathrm{Ni}(\mathrm{II})$ complexes with N-heteroaromatic selenosemicarbazones, Inorg. Chim. Acta. 362, 38133820 (2009).

[10] G. Zhao, H. Lin, S Zhu, H. Sun, Y. Chen, Dinuclear palladium(II) complexes containing two monofunctional $[\mathrm{Pd}($ en $)($ pyridine $) \mathrm{Cl}]+$ units bridged by Se or S. Synthesis, characterization, cytotoxicity and kinetic studies of DNA-binding, J. Inorg. Biochem. 70, 219-226 (1998).

[11] N. Gligorijević, T. Todorović, S. Radulović, D. Sladić, N. Filipović, D. Glođevać, D. Jeremic, K. Andjelkovic, Synthesis and characterization of new $\mathrm{Pt}(\mathrm{II})$ and $\mathrm{Pd}(\mathrm{II})$ complexes with 2-quinolinecarboxaldehyde selenosemicarbazone: cytotoxic activity evaluation of $\mathrm{Cd}(\mathrm{II}), \mathrm{Zn}(\mathrm{II})$, $\mathrm{Ni}(\mathrm{II}), \mathrm{Pt}(\mathrm{II})$ and $\mathrm{Pd}(\mathrm{II})$ complexes with heteroaromatic selenosemicarbazones, Eur. J. Med. Chem. 44, 16231629 (2009).

[12] P. Scovill, D. L. Klayman, C. F. Franchino, 2-Acetylpyridine thiosemicarbazones. Complexes with transition metals as antimalarial and antileukemic agents, J. Med. Chem. 25, 1261-1264 (1982).

[13] M. Carland, B. F. Abrahams, T. Rede, J. Stephenson, V. Murray, W. A. Denny, W. D. McFadyen, Syntheses and structural studies of platinum(II) complexes of O-methylselenomethionine and related ligands, Inorg. Chim. Acta. 359, 3252-3256 (2006).

[14] A. Molter, C. W. Lehmann, G. Deepa, P. Chiba, F. Mohr, Synthesis, structures and anti-malaria activity of some gold(I) phosphine complexes containing seleno- and thiosemicarbazonato ligands, Dalton Trans. 40, 9810 9820 (2011).

[15] S. Dasari, P. B. Tchounwou, Cisplatin in cancer therapy: Molecular mechanisms of action, Eur. J . P harmacol. 740, 364-378 (2014).

[16] P. Kumar, M. Clark (Eds), Clinical M edicine. 5th Edition, W.B. Saunders, London, 2002.

[17] E. Z. Jahromi, A. Divsalar, A. A. Saboury, S. Khaleghizadeh, H. Mansouri-Torshizi, I. Kostova, Palladium complexes: new candidates for anti-cancer drugs, J. Iran. Chem. Soc. 13, 967-989 (2016).

[18] A. R. Kapdi, I. J. Fairlamb, Anti-cancer palladium complexes: a focus on PdX2L2, palladacycles and related complexes, Chem. Soc. Rev. 43, 4751-4777 (2014).

[19] L. Tusek-Bozic, A. Furlani, V. Scarcia, E. De Clercq, J. Balzarini, Spectroscopic and biological properties of palladium(II) complexes of ethyl 2-quinolylmethylphosphonate, J . Inorg. Biochem. 72, 201-210 (1998).

[20] E. Gao, C. Liu, M. Zhu, H. Lin, Q. Wu, L. Liu, Current development of $\mathrm{Pd}(\mathrm{II})$ complexes as potential antitumor agents, Anticanc. Agents M ed. Chem. 9, 356-368 (2009).

[21] A. Divsalar, A. A. Saboury, H. Mansoori-Torshizi, F. Ahmad, Design, synthesis, and biological evaluation of a new palladium(II) complex: beta-lactoglobulin and K562 as targets, J. Phys. Chem. B, 114, 3639-3647 (2010).

[22] Z. M. Bugarčić, B. M. Mojsilović, V. M. Divac, Facile pyridine-catalyzed phenylselenoetherification of alkenols, J. M ol. Catal. A. Chem. 272, 288-292 (2007).

[23] Z. M. Bugarčić, V. M. Divac, M. D. Kostić, N. Janković, F. Heinemann, N. Radulović, Z. Stojanović-Radić, Synthesis, crystal and solution structures and antimicrobial screening of palladium(II) complexes with 2-(phenyselanylmethyl) oxolane and 2-(phenylselanylmethyl)oxane as ligands, J . Inorg. Biochem. 143, 9-19 (2015).

[24] T. Mosmann, Rapid colorimetric assay for cellular growth and survival: application to proliferation and cytotoxicity assays, J . Immuno M ethods, 65, 55-63 (1983).

[25] J. V. Kosaric, D. M. Cvetkovic, M. N. Zivanovic, M.G. Curcic, D. S. Seklic, Z. M. Bugarcic, S. D. Markovic, Antioxidative and antiproliferative evaluation of 2-(phenylselenomethyl)tetrahydrofuran and 2-(phenylselenomethyl)tetrahydropyran, J BU ON, 19, 283-290 (2014).

[26] V. M. Divac, A. Mijatovic, M. D. Kostic, J. Bogojeski, The interaction of organoselenium trans-palladium(II) complexes toward small-biomolecules and CT-DNA, Inorg. Chim. Acta. 466, 464-469 (2017). 